\title{
https://doi.org/10.46813/2021-136-181 \\ UNORGANIZED AIR RELEASES WITH RADIOACTIVE AEROSOLS FROM THE NEW SAFE CONFINIMENT OF CHNPP INTO THE ENVIRONMENT
}

\author{
P.G. Krukovskyi, Ye.V. Diadiushko, D.J. Skliarenko, I.S. Starovit \\ Institute of Engineering Thermophysics of NAS of Ukraine, Kyiv, Ukraine \\ E-mail: kruk_2@ukr.net
}

The New Safe Confinement (NSC) of the Chernobyl NPP, which isolates the destroyed reactor and the "Shelter Object" from the environment, is not airtight, so the problem is the lack of information on the flow of unorganized air with radioactive aerosols outside the NSC. This work presents computational model of the hydraulic state of the NSC, which allows to determine these flow rates through the leaks in the shells and building structures under the walls of the NSC. In addition to the developed model, the NSC hydraulic state model, created by neural network technology, was tested, which showed similar results and much higher computational performance, which allows its use for analysis and prediction of NSC's hydraulic state in real time.

PACS: 28.41.-i:89.60.-k

\section{INTRODUCTION}

The purpose of the creation and commissioning of the New Safe Confinement (NSC) of the Chernobyl NPP (Fig. 1) is to protect the environment during the removal of radioactive materials from the destroyed Unit 4 and dismantling of unstable structures of the destroyed "Shelter" Object.

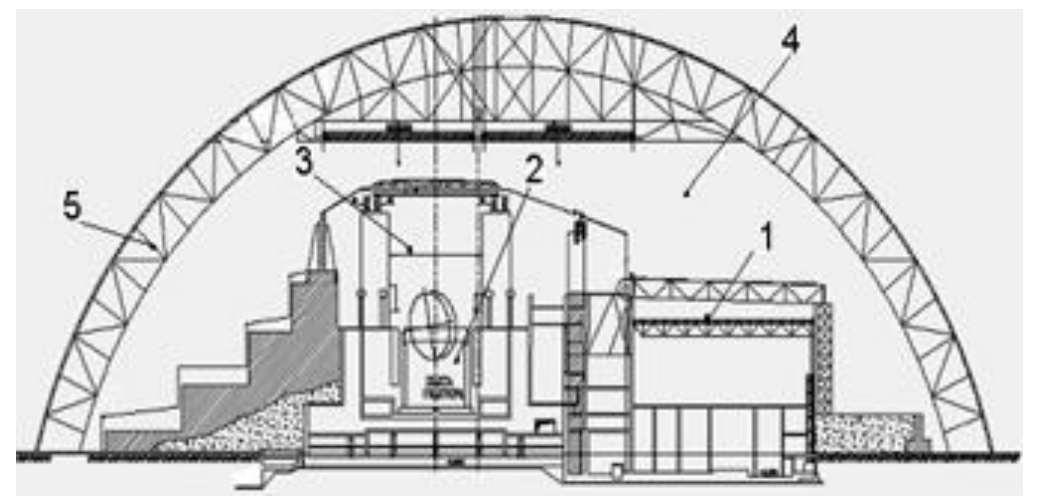

Fig. 1. Scheme of the NSC in cross section: 1 -turbine hall; 2 -destroyed reactor; 3 -central hall; 4 - main volume; 5-NSC's annular space

Since the complete tightness of such a huge structure $(\mathrm{W} \times \mathrm{H} \times \mathrm{L}=250 \times 110 \times 165 \mathrm{~m})$ is impossible to achieve, there are numerous air leaks from the NSC into the environment in the shells of the NSC and between the Western and Eastern walls and building structures, as shown in Fig. 2.

During the design of the NSC, the theoretical values of the leakage areas at the beginning and at the end of the 100-year service life of the facility were estimated (Table). After the NSC was moved over the SO (2016) and the planned sealing of all leaks (gaps) between the walls and building structures was completed by the developer (consortium NOVARKA) in 2017-2018, hydraulic tests were conducted and current areas of leaks were pre-estimated, which even at that time significantly exceeded the values of leakage areas, that should be at the end of NSC's term of the work (see Table, columns 2-3). It is predicted that the values of these existing Western and Eastern leakage areas will also increase significantly over time.

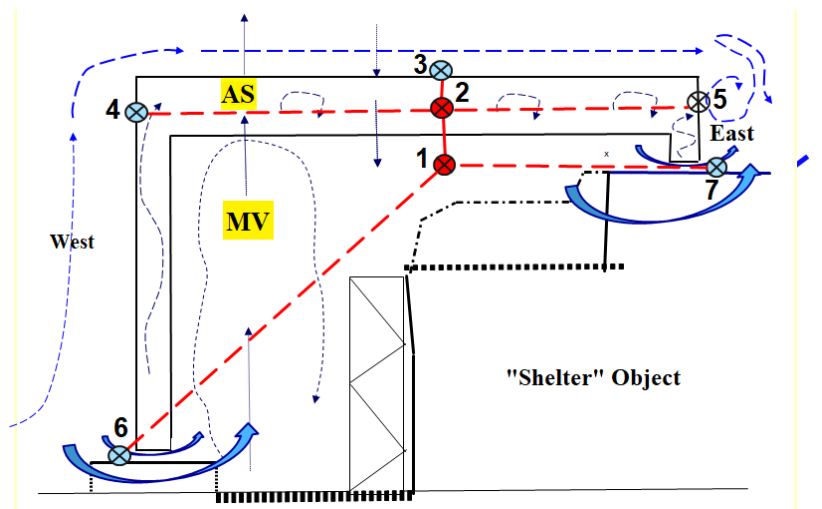

Fig. 2. Schematic representation of the nodes of the model of the hydraulic state of the NSC in longitudinal section: 1 -node of the main volume; 2 -node of annu-

lar space; 3 -node on the outer cylindrical surface;

4 -node on the outer surface of the western wall;

5 -node on the outer surface of the eastern wall;

6 -node on the outer part of the western leaks;

7 -node on the outer part of the eastern leaks.

Leakage areas estimated by NOVARKA - project and pre-estimated, as well as IETP 


\begin{tabular}{|c|c|c|c|c|}
\hline \multirow{2}{*}{$\begin{array}{l}\text { Places } \\
\text { of } \\
\text { leakage }\end{array}$} & \multicolumn{2}{|c|}{$\begin{array}{c}\text { Project } \\
\text { NOVARKA, m² }\end{array}$} & \multirow{2}{*}{$\begin{array}{c}\text { NOVARKA } \\
\text { pre-estimates, } \\
\mathrm{m}^{2}[3,4]\end{array}$} & \multirow{2}{*}{$\begin{array}{c}\text { IETP } \\
\text { estimates } \\
\mathrm{m}^{2}\end{array}$} \\
\hline & $\begin{array}{l}\text { Start of } \\
\text { operation }\end{array}$ & $\begin{array}{c}\text { End of } \\
\text { operation }\end{array}$ & & \\
\hline 1 & 2 & 3 & 4 & 5 \\
\hline $\begin{array}{l}\text { Outer } \\
\text { shell }\end{array}$ & 0.26 & 1.2 & 1.7 & 1.7 \\
\hline $\begin{array}{l}\text { Inner } \\
\text { shell }\end{array}$ & 0.24 & 1.1 & 5.0 & 6.1 \\
\hline $\begin{array}{l}\text { Western } \\
\text { leak }\end{array}$ & 0.6 & 0.6 & 3.1 & 2.5 \\
\hline $\begin{array}{l}\text { Eastern } \\
\text { leak }\end{array}$ & 1.8 & 1.8 & 3.9 & 4.8 \\
\hline
\end{tabular}

To date there are a limited number of works on the study of the hydraulic state of the ChNPP NSC, among which there are works on the distribution of air with radioactive aerosols inside the NSC [1], some focused only on unorganized air flow [2]. In [3, 4] air leaks areas between the NSC and the environment (ENV) estimations were performed, but the authors relied on a limited amount of operational data in the models used, which does not allow to obtain a reliable picture of the hydraulic state of the NSC-ENV system and, most importantly, to obtain air flow rates with radioactive aerosols (RA) from the main volume to the environment. This air leakage with the RA to the ENV is unorganized, uncontrolled and unfiltered of RA along with organized air leakage by means of an exhaust ventilation system with RA filtration. It should be noted that these unorganized air flow rates with $R A$ significantly depend on the speed and direction of the wind, as well as the mode of operation of the NSC's ventilation system.
Thus, the problem of the NSC is the lack of information on the airflow with radioactive aerosols from the main volume to the environment.

From the end of 2019, the Institute of Technical Thermophysics of NASU, presented by the authors of this publication, began to recieve operational measurements of the hydraulic state of the NSC, which allows to obtain more accurate values of leakage areas and, most importantly, outgoing air flow rates from the NSC, the results were presented on International Conference [2] and further presented in this publication.

Therefore, the aim of the work is to solve the above-mentioned NSC's problem by developing and demonstrating the NSC's hydraulic state model for determining the flow of unorganized air with RA from NSC to the environment through leaks under NSC's walls using NSC's hydraulic state operational data.

\section{METHODOLOGY OF DETERMINATION OF UNORGANIZED AIR FLOWRATES WITH RA}

To solve the problem, a computational-experimental approach was chosen, in the framework of which the model of the hydraulic state of the NSC is used, it`s parameters are found or specified according to field measurements of the parameters of the hydraulic state of the NSC (see Fig. 2). The availability of a large amount of operational data allows the usage models of the hydraulic state of the NSC to more accurately estimate both the areas of leaks and flowrates through them.

The methodology of modeling of the ChNPP NSC's hydraulic state (Fig. 3) shows the sequence for obtaining of an adequate model through the identification of model parameters (calibration) using operational data from the NSC and obtaining of the results of modeling in the form of flowrates through leaks (analysis and prediction), which will be directed to the NSC`s operator to control, predict and, subsequently, manage these flowrates.

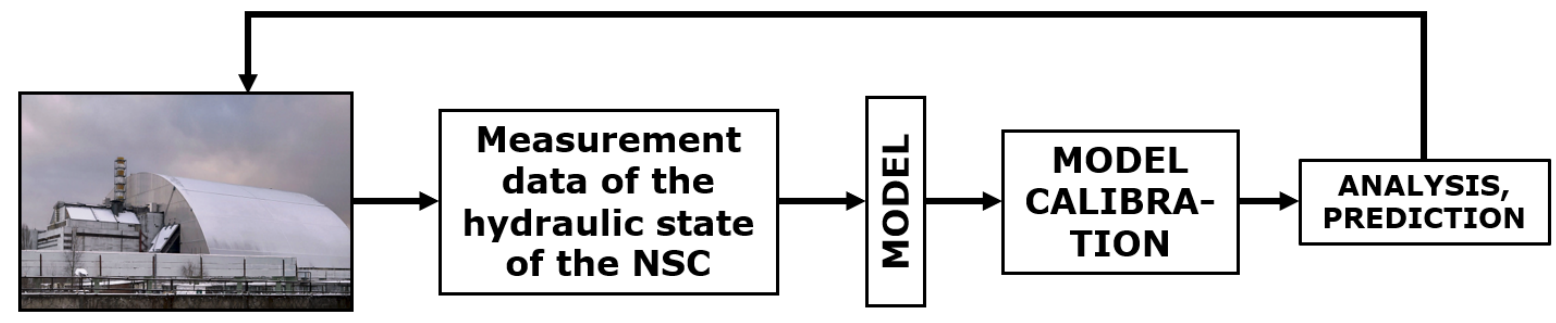

Fig. 3. Methodology for modeling of the NSC`s hydraulic state

Operational data of the hydraulic state of the NSC in the form of a continuous flow of pressure drop measurements between the Annular Space (AS) and the Main Volume (MV), between AS, MV and the Environment (ENV), as well as measurements of fan flowrates in AS, MV and climatic conditions (wind direction and speed (see Fig. 2)) enter the NSC's model, which evaluates the correctness of hydraulic coefficients. If the coefficients according to the selected criterion are estimated correctly, the model calculates the unorganized air flow with the RA from NSC's MV to the ENV through the Western and Eastern leaks (see curved blue lines in Fig. 2). If the coefficients according to the selected criterion are not evaluated correctly, then the hydraulic coefficients are refined (model calibration) and the unorganized air flow from the NSC with the concentration of RA in the ENV, which is also measured, is calculated. The organized air flowrates to the ENV filtered of RA by means of exhaust fans (VV) and special filters.

\section{NSC'S HYDRAULIC STATE MODEL}

As shown in Fig. 2, unorganized air exchange takes place from the AS to the MV through the inner shell of the NSC, because the pressure in the AS is always greater than the pressure in the MV (15...25 Pa) due to the constant operation of the discharge fan. In MV, on the contrary, exhaust fan always tries to maintain a small vacuum of 4...6 PA relative to the pressure in the ENV to reduce the flow of air with the RA from the MV to the ENV. 
The problem is that due to the constant change of pressures on the Western and Eastern walls of the NSC (WW and EW) in places of leaks (see points 6 and 7 in Fig. 2), which occur due to constant changes in wind direction and speed, the sign of pressure drops MVENV is constantly changing, which leads to the occurence of unorganized air flow with the RA from the NSC to the ENV. The pressures on the outer shell of the NSC at points 3-4 (see Fig. 2) are also constantly changing, which also leads to changes in flowrates though the leaks in the cylindrical wall (CW) and flat vertical walls of the outer shell of the NSC.

The model of the hydraulic state of the NSC consists of the equation of the balance of air masses in the volume system of the NSC-ENV for 7 nodes with concentrated parameters, of which 5 are external and 2 are internal nodes 1 and 2 (see Fig. 2). The internal nodes are computational, and the external are boundary, in which the absolute values of static pressures from the maps of pressure distributions on the surfaces of the NSC are set, obtained from [5], which were obtained by testing of the NSC's physical model in the wind tunnel. Between the nodes in the model there are 6 hydraulic connectons:

AS-CW, AS-WW, AS-EW, AS-MV, MV-WL, MV-EL (see dotted lines in Fig. 2).

Hydraulic connections determine the flowrates between the nodes, which allow to obtain the values of pressures in the computational nodes 1 and 2 for AS and MV.

The model is based on the Bernoulli equation [4, 6]

$$
G=R \cdot \Delta P,
$$

where $G$ - flow rate, $\mathrm{m}^{3} / \mathrm{s} ; \Delta P$ - static pressure difference between $\mathrm{P}_{\mathrm{MV}}-\mathrm{P}_{\mathrm{WL}}, \mathrm{P}_{\mathrm{MV}}-\mathrm{P}_{\mathrm{EL}}, \mathrm{P}_{\mathrm{AS}}-\mathrm{P}_{\mathrm{MV}}, \mathrm{P}_{\mathrm{AS}}-\mathrm{P}_{\mathrm{ENV}}$; $\mathrm{R}$ is the hydraulic conductivity, $\mathrm{m}^{3} /(\mathrm{Pa} \cdot \mathrm{s})$ in the form

$$
R=0,6 \cdot S \cdot \sqrt{\frac{2}{\rho \cdot|\Delta P|}},
$$

where 0.6 - flowrate ratio; $\mathrm{S}$ is the contingent area of the leak between the selected parts of the NSC and the environment; $\rho$ is the density of air.

Using equations (1), (2) and the balance of air flow $\mathrm{G}$ between the volumes of the NSC and the environment the equations of the model (3), (4) are concluded relative to the absolute values of pressures $\mathrm{P}$ in the volumes of $\mathrm{AS}$ and $\mathrm{MV}$ and have the following form for each moment of time of measurements of a hydraulic condition of NSC.

$$
\begin{gathered}
P_{a s}=\frac{R_{a s-w w} \cdot P_{w w}+R_{a s-c w} \cdot P_{c w}+R_{a s-e w} \cdot P_{e w}+R_{a s-m v} \cdot P_{m v}+G_{a s}^{+}}{R_{a s-w w}+R_{a s-c w}+R_{a s-e w}+R_{a s-m v}}, \\
P_{m v}=\frac{R_{a s-m v} \cdot P_{a s}+R_{m v-w l} \cdot P_{w l}+R_{m v-e l} \cdot P_{e l}+G_{m v}^{+}+G_{m v}^{-}}{R_{a s-m v}+R_{m v-w l}+R_{m v-e l}},
\end{gathered}
$$

where $\mathrm{G}^{+}$and $\mathrm{G}^{-}$are the flowrates of injection and exhaustion VUs in AS and MV, and the notation of the lower indices for $\mathrm{R}$ and $\mathrm{P}$ are given above.

Thus, the pairs of equations (3), (4) for each moment of time, when the measurements of the hydraulic state of the NSC are taken, create a system of algebraic equations, the solution of which allows to obtain flowrates for all 6 hydraulic connections: AS-CW, AS-WW, ASEW, AS-MV, MV-WL, MV-EL at the estimated values of the areas of 4 leaks $S$ between AS and ENV, AS and MV, MV-WL and MV-EL, as the main hydraulic parameters of the NSC. According to the methodology (see Fig. 3), before the flowrates calculations, the values of leak areas S between the selected parts of the NSC and the environment, which were used in previous calculations, are checked. If the standard deviation $\mathrm{F}$ of the calculated (m-model) pressure drops KP-OO from the measured (meas)

$$
F=\sqrt{\frac{\sum_{i=1}^{n}\left(\Delta P_{a s-m v}^{\text {meas }}-\Delta P_{a s-m v}^{m}\right)^{2}}{n}},
$$

is more than a certain value (assumed $1.5 \mathrm{~Pa}$ ), then the previously accepted areas of leaks $S$ must be specified by finding such values for which the value of $F$ will be minimal (by the inverse problem method). In (5) $\mathrm{n}$ is the total number of measurements of the hydraulic state of the NSC in the sample. If the value of F is less than the accepted value, then the found areas of leaks $\mathrm{S}$ are considered to be refined, the model is used to calculate flowrates through leaks (see Fig. 3). el:

The following assumptions were made in the mod-

1) leaks have the same nature, as a result of which a flowrate ratio of 0.6 was chosen;

2) taking into account the probable locations of leaks, certain surfaces were selected to determine the boundary conditions from the pressure maps that correspond to them.

\section{NEURAL NETWORK MODEL}

As will be shown below, model (1) - (4), which is based on the solution of the Bernoulli system of equations, will be used for a fairly large number (samples) of successive in time measurements of the hydraulic state of the NSC, which requires significant computational resources and calculation time. To reduce the calculation time, the model of an artificial neural network (NN) [7] was also used, which consists of an input (8 neurons), an output (1 neuron) and one hidden layer ( 8 neurons) (Fig. 4). The input data of the neural network is also the distribution of external pressures and flowrates of ventilation units, before the application of which additional standardization was carried out. The initial data of the model are the flowrates through the eastern and western leaks of the MV-ENV system, which were compared with the calculated values of the model (1) - (4). The adaptive Adam method (symbiosis of the gradient descent method and RMSProp) was used as an algorithm for standard error function optimization [7]. This approach with the parallel application of the NN model and the model (1) - (4) in attempts to reduce the calculated time close to the real time was successfully used in [8]. 


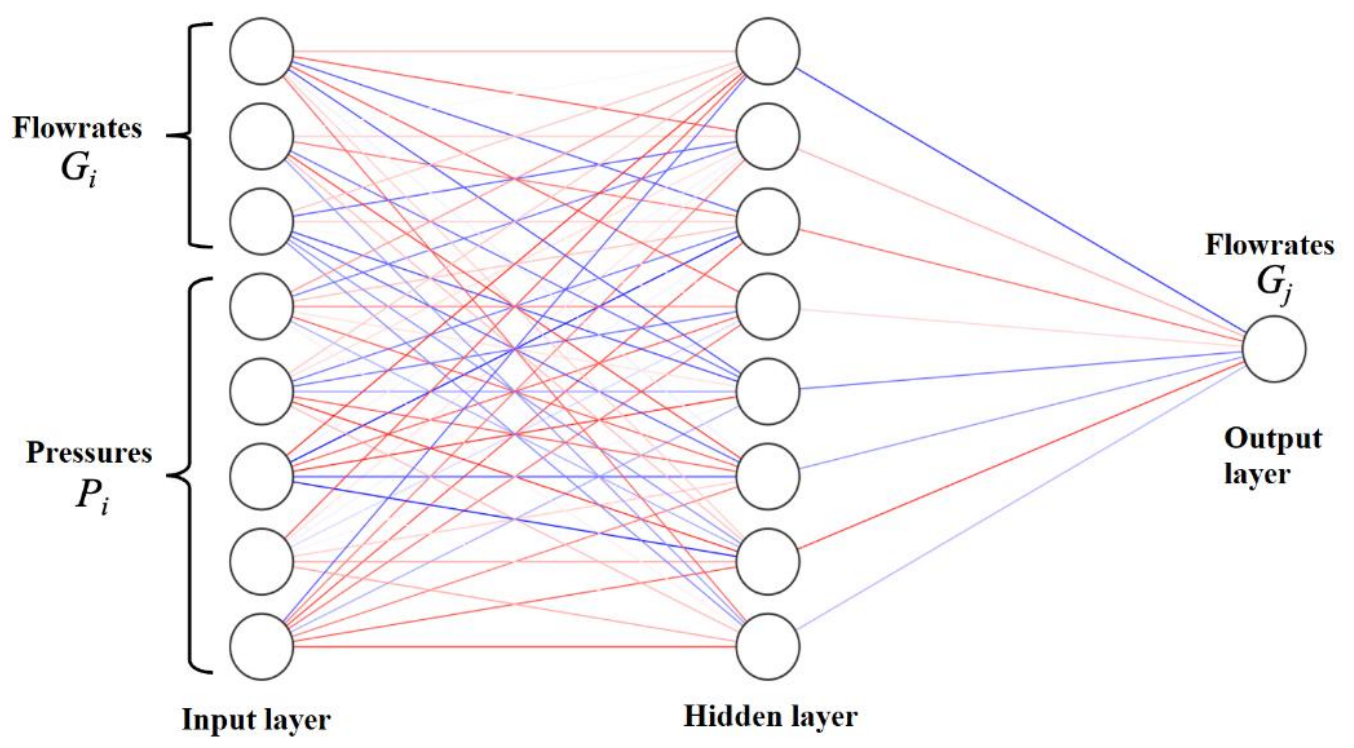

Fig. 4. Schematic of the neural network

\section{INPUT DATA}

Operational data of the hydraulic state of the NSC in the form of a flow (sample) of pressure drop measurements between AS and MV, between AS, MV, and ENV, as well as measurements of fan flowrates in AS, MV, and also climatic conditions (wind direction and speed, Fig. 5) are used as initial data for determination of unorganized air leakages with RA into the environment (areas and flowrates). Important initial data for flowrate calculations are the distribution of static pressures on the outer surface of the NSC at points (nodes) 3-7 (see
Fig. 2) at arbitrary wind directions and speeds. These data were obtained by experiments in the wind tunnel on a 1:300 model of the NSC [5]. They were used as boundary conditions to determine the areas of leaks from MV and unorganized flowrates from NSC's AS and MV to the environment.

From the Chernobyl NPP, a sample of NSC's hydraulic condition data was obtained in the amount of 677 measurements with a step of $1 \mathrm{~h}$ for the period from 17.01.2020 to 14.02.2020 for $676 \mathrm{~h}$. The dependences of the direction and wind speed are shown in Fig. 5.

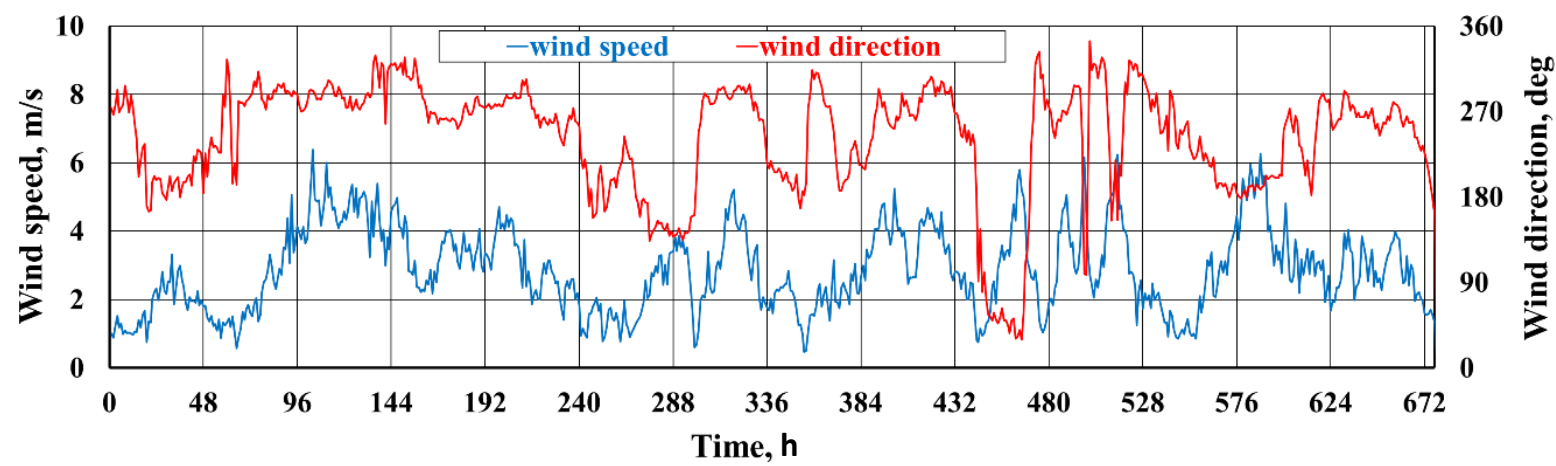

Fig. 5. Dependences of wind speed and direction on time

\section{RESULTS OF DETERMINATION OF AIR EMISSIONS WITH RA OUTSIDE THE NSC}

According to all the data of this sample, first with the help of model (1) - (4) and minimization of criterion (5) the values of the areas of leakage of unorganized air from the NSC to the ENV were clarified, which are given in column 5 of Table. The standard deviation (5) of the measured and calculated values of the AS-MV pressures was $1.19 \mathrm{~Pa}$, which is considered a satisfactory deviation. It seems to us that the leaks found are the most accurate, as they were found according to a large sample of measurements (677) in contrast to the significantly smaller number of measurements (6-10) used by NOVARKA before the commissioning of the NSC.
The obtained values were used to calculate the unorganized air flowrates in and out of the NSC in the form of the dependence of air flowrate on time, presented in Fig. 6. As a result, it can be seen that the flowrates through the western and eastern leaks under the walls of the NSC have both positive (air without RA enters from the ENV into the NSC) and negative (air with RA leaves the NSC into the ENV, painted red or blue) air flowrates values. This is due to the fact that the wind creates external pressure in the places of leakage (positive or negative, depending on the direction of the wind). Thus, changes in wind speed and direction, as well as VU flowrates in MV and AS determine the levels of unorganized air releases through the western and eastern leaks of the NSC (see Figs. 5 and 6). 


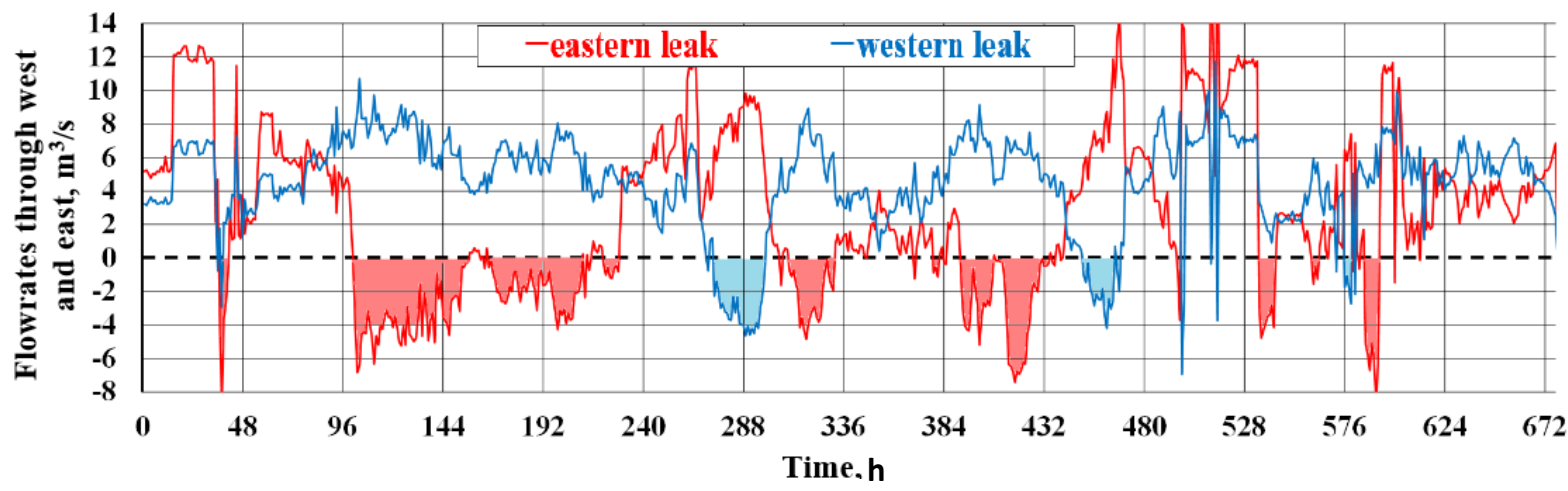

Fig. 6. Dependences of air flowrates through the western and eastern leaks of the NSC on time

The air flowrate time curves in Fig. 6 show that the negative (below zero) air flowrates (with the RA in it), which go through the western and eastern leaks outside the NSC, account for a significant share of 2400 thousand $\mathrm{m}^{3}$ (about $20 \%$ ) from positive and their share especially grows at the western direction and the raised wind speeds that for example can be observed in Figs. 5 and 6 between 96 and $155 \mathrm{~h}$ of operational measurements. Modeling of predicted flowrate values at speeds in the region of $10 \mathrm{~m} / \mathrm{s}$ shows an increase in air releases outside the NSC up to $50 \%$.

In general, from the analysis above it can be concluded that the given ChNPP control algorithm of AS and $M V$ in the period from 17.01.2020 to 14.02.2020 (see Fig. 6) is not optimal in terms of prevention of air releases from the NSC into the environment.

It should be noted that the model of neural networks (NN) showed almost the same curves of air flowrates through the western and eastern leaks of the NSC over time (see Fig. 6), for which it used the first half of the sample for "learning" and the second half for predictive calculations, which coincided with the results of model (1) - (5). The obtained low values of errors indicate the feasibility of further use of the NN model.

\section{AIR RELEASES WITH RA OUTSIDE THE CHNPP NSC}

Dependences of unorganized air flowrates through the western and eastern leaks of the NSC on time, obtained by modeling (see Fig. 6), allow to find the total (integral) air flow through these leaks outside the NSC for the period of 28 days from 17.01.2020 to 14.02.2020, which is equal to $\mathbf{2 4 0 0}$ thousand $\mathbf{~ m}^{3}$. According to the scenario of dismantling of unstable structures of the SO, the average monthly concentration of RA at the volumetric activity of $\beta$-emitting nuclides is approximately $210 \mathrm{~Bq} / \mathbf{m}^{3}$. Then the estimate of the value of the RA emission from the NSC in the conditions of dismantling of unstable structures of the SO will be

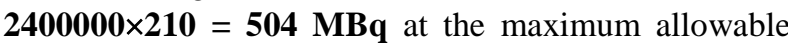
level of $700 \mathrm{MBq}$. When fuel-containing materials are removed, the activity of $\beta$-emitting nuclides will be higher than $210 \mathrm{~Bq} / \mathrm{m}^{3}$, which is considered as an example in [9] by modeling the distribution of RA in the NSC's volume when removing fuel-containing materials from the $\mathrm{SO}$.

Of course, the model can calculate not only the integral, but also the weekly, daily and hourly radiation load on the environment, provided that the Chernobyl

\section{NPP constantly delivers data of the NSC's hydraulic and radiation state for the model.}

One of the further plans to use the developed models is their adaptation and integration into the existing NSC's monitoring and management system. In fact, such models should become the so-called "digital twin" of the NSC's state, proposed in [10]. Such adaptation and integration of models will help to protect personnel and the environment during the transformation of the OS into an environmentally friendly facility.

\section{CONCLUSIONS}

- One of the problems of the NSC is the lack of information on the flowrates of unorganized air with radioactive aerosols from the main volume into the environment.

- Developed models and methodology for modeling the hydraulic state of the ChNPP NSC using operational measurements allowed for the first time to determine the continuous unorganized air flowrates with radioactive aerosols outside the NSC into the environment at arbitrary wind directions and speeds.

- The models allow to calculate the integral, weekly, daily and hourly radiation load on the environment under the condition of constant flow of data on hydraulic and radiation state of the NSC from the Chernobyl NPP.

- The developed models need to be adapted and integrated into the existing NSC's monitoring and management system, which will help to ensure maximum protection of personnel and the environment during the transformation of the "Shelter" Object into an environmentally friendly facility.

The authors thank the staff of the New Safe Confinement of the Chernobyl NPP for cooperation and providing data for the approbation of the developed model.

\section{REFERENCES}

1. V.G. Batiy, A.O. Sizov, D.V. Fedorchenko, A.O. Holodiuk. Dynamics of changes in the concentration of radioactive aerosols during the removal of fuel-containing materials from the "Shelter" object // Nuclear and radiation safety. 2015, № 4, p. 41-44.

2. P.G. Krukovskyi, D.I. Skliarenko, Ye.V. Diadiushko, S.O. Kondratenko. Analysis of unorganized air exchange of the New Safe Confinement with the environment (preliminary results of modeling according to operational data) // V International Conference 
"International Conference on Nuclear Decommissioning and Environment Recovery" INUDECO. April 27-29, 2020, Slavutych, Ukraine, p. 109-117.

3. P.G. Krukovskyi, M.O. Metel, A.S. Polubinskyi, V.A. Krasnov, D.I. Sklsarenko, A.I. Deineko. Model of thermogasdynamic, humid and radiation state of the new safe confinement and the "Shelter" Object // II International Conference "International Conference on Nuclear Decommissioning and Environment Recovery" INUDECO. April 25-27, 2017, Slavutych, Ukraine, p. 347-350.

4. Study of operating modes of ventilation systems of the main volume and annular space (Report) / SP NOVARKA. SIPNTM22B203_RTE00300, 2017.

5. Results of tests in a wind tunnel (Report) / SP NOVARKA. SIP NTE22B102-RPT00101, 2009.

6. T.M. Bashta. Hydraulic drive and hydropneumatic automation. M.: Publishing house "YOYO Media", 2012, 317 p.
7. I.L. Kashirina, M.V. Demchenko. Research and comparative analysis of optimization methods used in training neural networks // Voronezh State University Bulletin. Series "System Analysis and Information Technologies”. 2018, № 4, p. 123-132.

8. I.F. Yasinsky, F.N. Yasinsky. Simulation of a hydrodynamic problem using a combined neural network and dynamic model // Bulletin of ISEU. 2013, № 1 .

9. P.G. Krukovskyi, M.O. Metel, D.I. Skliarenko, et al. New safe confinement of the Chernobyl nuclear power plant (computational and experimental analysis in the design and operation). Kiev: Publishing house of LLC "Franco Pak", 2019, p. 247-254.

10. P.G. Krukovskyi, Ye.V. Diadiushko, V.O. Garin, et al. CFD-model as a digital twin of the radiation state of the New Safe Confinement of the Chernobyl NPP // Problems of Atomic Science and Technology. Series "Physics of Radiation Effects and Radiation Materials Science”. 2020, № 4, p. 54-62.

Article received 09.09.2021

\title{
НЕОРГАНИЗОВАННЫЕ ВЫБРОСЫ ВОЗДУХА С РАДИОАКТИВНЫМИ АЭРОЗОЛЯМИ ИЗ НОВОГО БЕЗОПАСНОГО КОНФАЙНМЕНТА ЧАЭС В ОКРУЖАЮЩУЮ СРЕДУ
}

\author{
П.Г. Круковский, Е.В. Дядюшко, Д.И. Скляренко, И.С. Старовит
}

Новый безопасный конфайнмент (НБК) ЧАЭС, который изолирует разрушенный реактор и объект «Укрытие» от окружающей среды не является герметичным, поэтому проблемой является отсутствие информации о расходах неорганизованного воздуха с радиоактивными аэрозолями за пределы НБК. Рассмотрена расчетная модель гидравлического состояния НБК, которая позволяет определить эти расходы через места негерметичности в оболочках и строительных конструкциях под стенами НБК. Дополнительно к разработанной модели была проведена апробация модели гидравлического состояния НБК, созданная по технологии нейронных сетей, которая показала близкие результаты и гораздо большую расчетную производительность, что дает возможность ее использования для анализа и прогнозирования гидравлического состояния НБК в режиме реального времени.

\section{НЕОРГАНІЗОВАНІ ВИКИДИ ПОВІТРЯ 3 РАДІОАКТИВНИМИ АЕРОЗОЛЯМИ IЗ НОВОГО БЕЗПЕЧНОГО КОНФАЙНМЕНТА ЧАЕС В ОТОЧУЮЧЕ СЕРЕДОВИЩЕ}

\section{П.Г. Круковський, С.В. Дядюшко, Д.І. Скляренко, І.С. Старовіт}

Новий безпечний конфайнмент (НБК) ЧАЕС, який ізолює зруйнований реактор і об’єкт «Укриття» від оточуючого середовища не $\epsilon$ герметичним, тому проблемою $\epsilon$ відсутність інформації про витрати неорганізованого повітря з радіоактивними аерозолями за межі НБК. Розглянута розрахункова модель гідравлічного стану НБК, яка дозволяє визначити ці витрати через місця негерметичності в оболонках і будівельних конструкціях під стінами НБК. Додатково до розробленої моделі була проведена апробація моделі гідравлічного стану НБК, створеної за технологією нейронних мереж, яка показала близькі результати і набагато більшу розрахункову продуктивність, що дає можливість їі використання для аналізу і прогнозування гідравлічного стану НБК у режимі реального часу. 